\title{
Trailblazing IPEd Praxis in Mountain Province, Philippines
}

\author{
Julie Grace K. Mi-ing, MA ESL, Ed. D. \\ Mountain Province State Polytechnic College, \\ Bontoc Campus, Mountain Province, CAR, Philippines
}

\begin{abstract}
This study explores the praxis of Indigenous Peoples Education in Mountain Province, Philippines. The data were gathered through profiling. Likewise, interviews and Focus Group Discussions with selected IPEd experts and advocates; and, analysis of the secondary sources such as documents, reports, and pertinent provisions of the schools and line agencies in their conduct of IPEd were undertaken. The data shows that there is a strong adherence towards cultural preservation in the basic and higher education institutions, and government agencies. There have been implementation of various cultural development platforms with set mandates and organizational structures of IPEd aligned to their respective thrusts and mandates. The learning of culture is strengthened in various formal education spheres. The communities' cultural ideals complement the learning content of modern education.
\end{abstract}

Keywords: basic and higher education, indigenous peoples education, and government agencies.

\section{Introduction}

In this era of modernization and cultural homogenization, many Indigenous Knowledge Systems and Practices (IKSPs) are in the verge of extinction (Valencia, n.d.). The loss of identity and culture today alarms the members of the indigenous cultural communities (ICCs) or indigenous peoples (IPs). They have expressed that the balance of culture and diversity with development may be resolved through education (Michie, 1999). The IPs have their own culture: traditions, way of life bounded on their own knowledge systems, values, spirituality, and capabilities (Valencia, n.d). Overall, the Philippines, majority of the people are the IPs with their distinct culture as embodied in their way of living as their various IKSPs. Indigenous education is one way of building up the IPs welfare and development. Moreover, IP Education is grounded in the basics of human nature (Cajete, 1994). The classroom is viewed as the ancestral domain of the IPs. These ancestral domains are where life lessons and experiences are ought to be learned from.

Cordillera Administrative Region, a home for indigenous peoples in the northern part of the Philippines, has always been known for having a rich or vast coverage of IKSPs (Kinomis, 2016). CAR is a home to many Igorots with diverse and as well as peculiarities of similarities of IKSPs. It is composed of the six provinces. These are: Benguet - "The Salad Bowl of the Philippines"; Ifugao "The Stairway to the Sky"; Mountain Province - "The Weaver's Paradise"; Apayao - "Cordillera's Last Frontier for Nature's Richness; Abra - "Home of the Itnegs or Tingguians"; Kalinga - "The Home of Macli-ingDulag"; and, Baguio as the Melting pot of Cordilleran Culture and the Summer Capital of the Philippines. Collectively the people are popularly known as Igorots, which are grouped into a number of ethnic or ethno-linguistic groups: Applai, Balangao (sometimes known as Baliwon), Bontok, Kankanaey, Iwak (sometimes known as Iowak, Owak), Karao, Ibaloy, Kalanguya, Ifugao, Isnag (sometimes known as Isneg or Apayao), Kalinga, and Tingguian (sometimes known as Itneg) (NCIP, 2017; Aplaten, 2010).

In Mountain Province, each of the 10 towns has their own versions of the various IKSPs culture. Such of these reflects distinct rich cultural heritage as encapsulated in aspects of geography, 
history, people, materials culture, rites/rituals, and traditions. These are seen in traditional attires as reflected in their weavings, gender based attires; music with their musical instruments (brass/metal instruments, bamboo instruments, wooden instruments, indigenous songs and chants, and hymns and march, dances, festivals.

The Philippine education programs have various methods as Rights Based Approach, Philippines IP Core Curriculum, the indigenous peoples' education curriculum framework, and Indigenizing the Curriculum as reflected in the DepEd IPEd program. In the tertiary education, there are non-directed and/or mandated frameworks and related programs.

National IPEd Policy Framework is directed through DepEd. Manifestation of the framework is through the promotion and sustainability of IPs culturally rooted learning experiences through the integration of IKSPs in all learning areas and processes. This recognition and inclusion of IKSPs will pave the way for the provision of universal and equitable access of all IPs of quality and relevant basic education services towards functional literacy for all (DepEd Order \# 32, s. 2015). This is likewise supported by the project on the development of Indigenous People's Core Curriculum that emphasizes especially on the cultural spaces, its peoples, and their ideals towards the articulation for self-determination. Relatively, the IPRA law serves as the basis for the establishment of the indigenous schools in the country (Abayao, 2014).

However, in the most recent times, the rapid transformations in technology have altered the nature of culture and its exchange (Vadil, 2008). Amidst this period is likewise the vast array of problems that have been experienced by many indigenous people students who attempted to learn subjects grounded on western traditions (Aikenhead, 1997; Michael, 1999), although there are occasions where these students prove to be able to acculturate themselves between subcultures (Medvitz, 1985; Waldrip\& Taylor, 1999). Moreover, indigenous peoples as a whole face diverse difficulties. They are often forced out from their lands; believed to be as minority members of the society; and are separated from the banquet of capitalism. These cold situations persist. These disturbing realities may be primarily associated to the deprivation of access to quality education (Peralta, 2014). The need then to prioritize their needs is helpful for them in bridging and utilizing their IKSPs. This fact is no difference with Briggs' (2005) on the use of indigenous knowledge as an alternative way of promoting development in poor rural communities in many parts of the world. Revisiting indigenous knowledge is appropriate with a hope for its practical aspect in curbing the problems. Possible problems may likewise persist through the reviews of these IKSPs such as tensions between western science and indigenous knowledge systems; the problem of differentiation and power relations; the romanticizing of indigenous knowledge; and the all too frequent decontextualization of indigenous knowledge. Thus, to further contribute to the body of knowledge is the study on the different groups of indigenous people in the Philippines, particularly in the Mountain Province of the Cordillera through their education initiatives and programs in various spaces, including but not limited to formal education.

This study explored the landscape of indigenous education, outlining key features of the province's perspectives on learning and teaching of IKSP knowledge. It is profiling a contemporary, culturally based modalities and platforms of educational process and initiatives of the IPs in the modern spaces of learning and teaching. The idea of carefully monitored instruction programs and researches mandated in the educational system can provide excellent guidelines for policy making and planning new program and framework viable and useful to people's education and assimilation in the modern milieu.

\section{Method}

\section{Participants}

This study was confined to IKSP advocates, practitioners and experts in different selected basic and higher educational institutions in the province Mountain Province. The 35 participants were those who have more than three years of experience in their respective fields.

\section{Design}

This qualitative research method assessed the educational praxis on IPEd of Mountain Province along research, instruction, and extension through profiling (framed in the IPEd mandates). 
Secondary resources, Focus Group Discussion, and interviews were mainly used to gather data. Other data-gathering tools include documentary analysis.

\section{Materials}

The research followed the profiling steps to scan the IKSPs integration praxis along research, instruction, and extension in the educational institutions and selected line agencies. These were coupled with unstructured interviews which were undertaken to verify ad validate/ triangulate the responses made by the respondents in the situational analysis, FGD and assessment of praxis.

\section{Procedure}

Participants were met through focus group discussions and one on one interview at their respective offices and schools. It was explained to them that the researcher was interested on their school programs on indigenous people's education initiatives. They were asked to answer honestly as well its implementation. They were told their responses will be treated with utmost confidentiality.

When the interviews and discussions were completed, were transcribed, the researcher requested for Curricular program offerings of various education curriculum through the Registrars', this were supplemented with their relative mandates on curricular praxis, and IPEd programs or initiatives and instructions for document analysis.

\section{Results and Discussions}

Like other most places where IPs live, Mountain Province had been blown with a lot of 'wind of changes' diaspora. There are major transformations and democratizations. These changes are observed with the utilization of the material culture and knowledge based practices as reflected on the tradition of practice in assimilation to modern society.

\section{IPEd Programs and Initiatives in Schools and Line Agencies: School of Living Traditions}

Mountain Province has long recognized the importance of IKSPs in the educational and social institutions. The educational institutions and line agencies are the primary venues in providing relevant learning and teaching vis-à-vis the cultural milieu. These spaces are the ancestral domains of the IPs consequently living to the spaces today - the global setting and aspirations. These institutions are compelling elements of the province's society in bridging the gaps of the past to the present societies. There are number of evidences that show the IPEd activities had long been established in various sectors of the province amidst the presence of the larger mainstream population and other government structures.

One of the tangible proofs is on the showcased cultural heritage development reflected on various platforms of applications with the tangible and intangible material cultures (also termed cultural properties). The former is on the material culture that are referring to objects, implements, and other artifacts while the later are the customs and beliefs either reflected and/ or manifested with the material (tangible) objects or in writings and digital outputs as e-file documentaries and photo documentations. Such materials and platforms of use meant collectively to strengthen cultural consciousness and welfare of the community. These are shown on the following findings of IPEd praxis of most Mountain Province schools and line agencies.

\section{A. Culturally Rooted Instruction: Contextualization, Indigenization, Localization}

The schools in the province had long been recognized to be inculcating indigenous knowledge systems and practices (IKSPs) in educational and related affairs vis-à-vis the community activities. However, with the release of DepEd order \#62, s. 2011, adoption of the National Indigenous Peoples (IP) Education Policy Framework (DO. 62, s. 2011), the practice was further escalated and unified.

Complementary, the present Mountain Province DepEd Division IPEd Coordinator, Jacinto Yassan affirmed, "IPEd is not about going back to the past; it is the contextualization of Curriculum for learners to be globally competent and culturally-rooted. IPEd is a plus factor to advance the IP skills relevant for today's demands... IPEd core advocacy is contextualization... lagyanngbuhayang (give life to [learning]) content set in the curriculum." These are primarily realized as reflected through the province's IPEd set of roadmap. This dwells on four main domains: Research, Planning, Monitoring and Evaluation; Curriculum Development Instruction, Education Resources and 
Facilities; Governance and Policy Development; and Partners and Stakeholders. The IPEd of Mountain Province aims to produce culturally rooted and globally competent graduates (MPSDO, n.d.).

Further, secondary sources, documents and mandates show the established IPEd in the province. These are the RM No. 312, s. 2016 - IPEd Roadmap 2016 to 2021; RM No. 158, s. 2016 FY 2016 IPED Work and Financial Plan, Transition and other Program Implementation Concerns, RM No. 032, s. 2014 - IPED Review of All Baseline Data Forms (DepEd - CAR, 2014); RM No. 223, s. 2016 - Search for the Best IPEd Learning Resource Center, Mountain Province IPED Framework, Mountain Province IPED Roadmap among other provisions. The mentioned mandates provide a pillar to the reinvigoration of cultural practice and preservation across the functions of the schools. The Mountain Province Schools Division IPEd Plan likewise shows the division's established mechanisms on its feasibility. It formed technical working group from division superintendent, division IPEd Coordinator, per subject area, per district, administrative officer, accountant, planning officer and LRMDS coordinator; 24 Mtn. Province District IPEd coordinators, having each both 12 coordinators for elementary and secondary; and, roles and functions of the School IPEd coordinators summed as to advocate IPEd in the school and to all partners and stakeholders among others.

Through the years, especially from 2011 to the present, intensified IPEd activities have been observed with the upgrading of spaces and outputs in the schools. The spaces are the resource centers of learning; these are gradually being put in place like the development of IPEd learning resource centers. Also, there are IPEd corners in the classrooms alongside the subjects being taught vis-à-vis the developmental levels of the students. The usual elements found here are photo galleries of each locality's place, system of knowledge and other materials of the locality. Likewise, there are outputs of students' and teachers' photos on their community engagements or students' output in other subjects that features the colors of the locality's IKSPs.

\section{b. The SLT Flagship of the Private Schools: Cultural Practice and Preservation}

The private schools in the province are likewise under the auspices of DepEd; thus, these private schools anchor their programs and activities following the mandated provisions of the government. The SLT schools are among the private schools in the province and are under the Vicariate Mission Schools, Mountain Province District (CCFI, 2016). These are the Bauko Catholic Schools (F-1965), Poblacion, Bauko; Holy Rosary High School (F- 1954), Kayan, Tadian; Immaculate Heart High School (F- 1949), Poblacion Natonin; San Alfonso High School, Poblacion Sabangan; Saint Vincent's High School (1930), Poblacion, Bontoc; Saint Vincent's Elementary School (F-1915), Poblacion, Bontoc; and, Saint Vincent's Kinder School (F-1911), Poblacion, Bontoc. These schools follow the strong hold of the school and church with the community for students' growth and development.

However, SLT schools have long been also observing curriculum that is culturally-rooted. The principles follow interfacing curriculum as the approaches on teaching are on: Enculturation, Interculturation, and Transculturation as taught by the SLT pioneers in the vicariate schools' way back on 2002 by then Rev. Bishop Francisco Claver, the Father of the SLT in Mountain Province Vicariate. Bishop Claver led a great interest in IPs vis-à-vis the today's generation. The schools present the works of the pioneers of the SLT supported by the cultural development work of the Bishop and its ministries. Indeed, the Bontoc - Lagawe Vicariate schools are practicing SLT for almost two decades now. Furthermore, Gao-ay (2009) discussed in her article, SLT: Bridging the School Curriculum and Culture as this is a re-invention of deeply integrated culture in the academic curricula. It is making culture itself as an instrument in realizing learning goals in the four corners of learning. Learning is practiced and applied in everyday life. With the said modality, culture is learned and preserved. This will assure that culture will live on to the next generations (UNESCO).

Tracking the SLT activities, conventions are the highlights of the program. Retracing the themes through the years of SLT conventions, these adhere with the faith, culture and education in the light of the 'global' world. To mention some of these are: "Inculturation towards Sustainable Development and Peace" (2012); "Deepening Faith and Culture through Transformative and Innovative Education" (2015); and, "Vicariate Schools: Missionary Disciples of Faith and Culture" (2016). The convention is now annually being held. Selected students from the six various schools are joining in the said activity. Moreover, SLT aims to identify the aspects or components of the 
traditional culture that are considered important to cultural community and should be passed on to the next generations.

It can be noted that the establishment of SLTs is in response to United Nations Educational, Scientific and Cultural Organization's (UNESCO) call for the preservation of cultural heritage by preserving it in a living form and ensuring its transmission to the next generation. This program specifically focuses on the conduct of indigenous skills, and techniques to the young. It is also anchored on the mandate of the National Commission for Culture and Arts (NCCA) specifically on the conservation and promotion of the nation's historical and cultural heritage recognizing and preserving the endangered human cultural resources such as weavers, chanters, dancers and other craftsmen, as well as the conservation and development of such artistic, linguistic and occupational skills that are threatened with extinction (Saley, 2012).

One of the SLT pioneers, Rev. Fr. Andrew explained that SLT schools are the SLT centers by themselves - a space of cultural immersion and learning. This education follows enculturation ( which is the steady acquisition of the culture) interculturation (learning from diverse cultures), and transculturation (application and capacitating others through the learned indigenous knowledge systems and practices).It was likewise added that the establishment of the SLTs is in response to the initiatives of the church and schools in the vicariates on going back to understanding the compelling traditions of the Mountain Province peoples' life ways, and traditions; the interfacing curriculum (which observed as support on the D.O. 62 as discussed above on IPEd implementation as mandated by DepEd); and, SLT convention which is the coming together of all vicariate schools for interculturation and transculturation through the showcase/ exhibition of various cultures of which each school's locality students come from. The various activities herewith are focused on various streams of cultural topics in relation with each respective themes and programs. These are manifested in talks or symposia with resource speakers coming from the community or in the line agencies advocating on cultural education and SLT platforms; street dancing competition, indigenous games anchored in the typical tasks and leisure in the community (log rolling, kadangkadang, log carrying, leg wrestling, and chicken catching, ag-agto, husk relay, and eneta-an); poster making contest (on the theme), literary musical presentation (uggayam and chaing - the native chants); and, cultural presentation. With regards to SLT schools' museums or centers for showcase of material (tangible) and intangible culture, it was pointed out that some schools have started establishing the physical structure of the center in the recent years.

Indeed, the SLT identifies the features or components of their students' traditional culture that are considered important to the cultural community. These are deemed to be imparted to the youth so enduring values and traditions can be perpetuated. To some, culture may be a hindering factor to development - the process of preserving the culture and adhering to the usual practice may crash with the rising of technologies and scientific progress. However, the role of the SLT is to combine culture with advancements. It is embracing traditional practices while investing on developments as well. The compelling learning goals of the SLT program are the revitalization and re-invention of the customs and traditions yet globally competitive.

Escalating with the regions' advocacy whether it is a private or public school, it was found out in series of reports that Cordilleras is now the epitome of the IPEd not only in the country but also in other ASEAN countries (Memebrere, 2016; Empian, 2016). Department of Education Undersecretary for Legal Affairs Albert Muyot said that the Cordillera is being eyed as the country's leader in the implementation of the IPEd of the agency. "CAR has done a great job in providing the model for IP education in the Philippines," said Muyotin a Regional Basic Education Congress(2017). It was likewise pointed that the region's model made IPEd viable and sustainable and inclusive starting from its basic education. DepEd in the Cordilleras were advance and did not wait for the central office's recommendations for the implementation of IPEd (Memebrere, 2016).

Like in the basic education, the schools in the higher education, MPSPC and Xijen, have long been active in the call of cultural heritage advocacy. These however are reflected differently by the said schools. Common advocacy is on the adherence of letting the students to be active participants on cultural programs lead by line agencies such as festivities and other culture and the arts undertakings. There is the participation of the Students Cultural Arts Group of MPSPC and Xijen's on festivities for cultural competitions, and involvements during Am-among (Bontoc Town 
Fiesta) and Lang-ay (province's festival). On education, other free trainings are enjoyed thru the provincial office and the National Commission on Indigenous Peoples for NCIP grantees. There are the participations of the NCIP grantees on IP and IPEdfora. These NCIP grantees came from all over the tertiary levels of the Cordillera Region as assisted by the NCIP.

Thrusts and other mandated functions of MPSPC is the integration of IPEd in the holistic school experiences of the students and faculty members. There are programs for graduate and undergraduate studies. To cite are the additional subjects: IKSP and IPEd and the multicultural education approach across programs. The said subjects are the creations of the said college. Also, there is the presence of Master of Arts in Rural Development Major in IPEd for the Graduate School. These are seen as unique and strong flagships of the institution on curricular program offerings. In research, vast array of topics on theses and dissertations in the all programs excluding still the undergraduate researches give a startup compilation of materials for cultural studies. These set of studies can be categorized under various streams. These are more on governance, entrepreneurship (utilizing local cultural properties), sciences, health and education. The research input to policy makers, enhance knowledge and skills in dealing with interactions with social systems to promote education and sustainable development, and cultural mapping vis-à-vis the modern experiences of traditions. Moreover, there are 131 cultural studies completed by the MPSPC personnel that have been presented in various local, national and international fora. With the recent and timely write shop trainings on Cordillera Studies of faculty researchers given, further cultural awareness and skills on researching on this genre had been raised.

\section{Schools with Line Agencies: Advocates of Cultural Spaces and Industries}

Stakeholders from the line agencies are the partners of the community and school in the implementation of the IPEd and/or advocacy on cultural heritage practice, preservation and development. Evidences of these includes but not limited with festivities, trade and industry (promotion of local crafts and products), education, custom and tourism (Museums, heritage sites). Evident actions the local festivities fully aligned with authentic and traditional life-way and ideals. Locals' products are emphasized. On education spaces, museums and libraries strengthened their book holdings. There are relevant books designated on section in the libraries such as the municipal libraries, and provincial libraries as well as the multifaceted services being offered by the provincial tourism office and the National Commission on Indigenous People files and collections. The libraries have some collections of the cordillera history books such as those that are written by Henry Scott, one of the early writers on Bontoc Culture and History. Others include as well as learning resources made by teachers such as those that are from DepEd as compiled by the provincial librarians themselves. Museums such as the Binangi of Tadian (named after the locals' name of the indigenous house), Tadian Municipal Museum, and Bontoc Museum house the cultural appreciation and education of the locals' cultural properties and knowledge system reflected on both the tangible displays (of real objects, photo documentations, and books) and the curators' guide (as thru lectures, or interviews). Tadian Municipal Museum is municipality's owned while Bontoc Museum is Church owned and managed by nuns. These museums benefit both locals and non-locals especially on cultural education that also give venues for exhibits and visitation sites of learning during festivals and other provincial and local government unit relevant events other than the academic field for educational trips.

Significantly, NCIP has also long been closely working with DepEd as shared by NCIP IPEd Coordinator, Lilibeth Chapap. They worked collaboratively in framing the Mountain Province IPEd Framework. Also, they are helping with the training of teachers teaching IKSPs thru lectures and seminars in partnership with the office. They likewise have been assisting researchers on the conduct of IKSP and IPEd researches. While assisting researchers and granted studies in the province, NCIP was also able to accumulate copies of some of these completed researches and other pertinent books as donated for the office. To mention some of these collections are "Igorot Value Systems and Cultural Protocols: Learning from the Igorot Cordillera BIMAAK Europe from the 6th, ICBE Convention" (Fiar-od, 2011), and "Nan NatagowanTaku" (Aplaten,n.d.).

For the Provincial Tourism Office, interviewed Mr. Lawey has raised the office's programs that usher documentations of all cultural properties of the province. The office notes on the coming up of database for the IKSPs and documentations yielded from their works. Thru write ups and documentations, they could help in the collection and showcase of these materials. Others were 
recognized and are actually used in the various province tourism affairs and festivities, and in the Monitor Publication of the Province. The unit had been including it as part of their targets. The existences of cultural festivals in the province where cultural traditions are highlighted are likewise observed annually. Provincial wide festival is the grand Lang-ay affair which is usually scheduled on the month of April. Various cultural activities are likewise showcased. This affair is being spearheaded by the provincial office in collaboration with other line agencies and private institutions. Similarly, there are also municipal town fiestas in the 10 municipalities in the province. Annual affairs here are headed by the respective municipal and barangay local government units.

Other units in the province likewise had been on IKSPs generation thru competitions and feasts. This can be seen with the Provincial Department of Health Office recognizing the IPs participation in development specifically on health system supported with by the municipal DOH with their call, Am-among for Health 2018. This calls for all offices and schools (dated February 5, 2018) on their participation. Likewise, schools and line agencies have been closely working together for generation and documentation of IPs' IKSPs and all cultural properties. The outputs are the representations of the past that can be made useful by the community for social empowerment and development. The remnants of the past that are found in the museums and learning centers reflect on who the people are; its integration in the educational institutions and other line agencies' programs and activities enlivens it further in this modern world. The efforts then are being place to the importance and relevance of these cultural properties in shaping who the people are. Up to date, there could be more proliferation of researches on IPs in response to the initiatives in various agencies and schools on cultural revitalization and development across programs with the advantage of looking for means to preserve and protect the communities which is likewise situated in the ancestral domains - the world of the IPs worth to be prepared for center's knowledge and material data. IPEd learning resource center is one of the indicators of the implementation and adherence on the praxis of IPEd in learning institutions. Only some of the schools have initiated on achieving it thru IPEd Corners in their respective classrooms. IPEd Learning Resource Center in schools houses a number of prepared Contextualized Strategic Instructional Materials (SIMs) that are school- based quality assured and others have passed the LRMDS quality assurance. SIMs is centralized on teacher-made story books featuring local stories, and workbooks on Mother Tongue Based as prepared by teachers. Most of the SIMs are on short stories and mathematical workbooks addressing students' needs on reading comprehension and number problems. Other materials found here are on the traditional implements of people and diorama of indigenous house structure. Following the DepEd Regional Memorandum Number 223, 2016 or the Search for the Best IPEd Learning Resource Center (DepEd, 2016), monitoring of these centers are therewith strengthened. This is in adherence to DepEd Order No. 6 s 2011 or the National IPEd Policy statement.

IPEd learning resource center features tangible and intangible cultures through e-files, history books, photo exhibits, SIMs, art, crafts, local history books, thesis and dissertation files. Interestingly, there are also materials provided by the Provincial Tourism Office to complement and complete the center such as promotional brochures, pictures and documentaries. All tangible cultures like artifacts are properly documented as with descriptions; to cite: furnay is a large clay jar used as a container for drinking water and safeng, and, tupil (Central Bontoc)/ oppig (Bayyo) which is a woven container (made out of rattan or bamboo) with cover but more in depth which serves as a lunch box when one goes to the fields. Another artifact is on accessories such as: akusan which is woven belt or girdle worn around the waist of women. It has a secret compartment used to hold valuable items such as jewelries, coin money, etc. that women carry along with them for safe keeping) and ananga (Sadanga) which is a traditional woven raincoat made of bamboo and rattan.

Further, the existence of IPEd centers and museums are complemented with the international and national policies and mandates on IPs in various programs and works in the province. All of these are in support with the community's need and interests on cultural heritage preservation thru the material and non - material cultures of the people of the province and nearby. Significant positive impacts of having these centers for the students and other stakeholders are for enriching the minds and soul. The mentioned materials and knowledge readings are nourishment for the brain and soul. Functional libraries and museums open minds to wonder and learn or even relearn things of people and its heritage. Consequently, Both represent of how much society values ordinary people and their endeavors to educate themselves, find refreshing new insights, learn new things and find answers. Above all, a library is home, to intellectual wealth, while a museum is the 
home of people's collective memory. The need for spiritual refreshment and renewal is also paramount, and both museums and libraries cater to this, too (Kasvio, 2008; Haavisto, 2017).

Among all initiatives on IPEd praxis in the province on education and line agencies' advocacies as presented above, it can be gleaned from the result the common pattern of similar praxis across the said institutions. Supplementary, it still can be gleaned that there are rooms needed to be unlocked and gaps to be studied. In today's supposed enlightened cultural climate led by the boon of technology, understanding of the Cordillera as a geographical site, and as a marker to identify a Philippine ethno-linguistic group is still limited (UC, 2012). One thing that stands out amidst peoples' diversity is the harmonized platforms of uniting people through culturally responsive education.

\section{Conclusion}

A profile scanning of the indigenous people's education praxis in Mountain Province reflected a strong adherence towards cultural preservation. Basic education and higher institutions, and government agencies implement various cultural development platforms with set mandates and organizational structures of indigenous peoples' education (IPEd) programs aligned to their respective thrusts and mandates. For learning institutions, the praxis of indigenous people's education is done through contextualization and integration of authentic experiences in the teachinglearning processes. Government line agencies throw their support and link with the academe through socio-cultural cultural shows, spaces of education, competitions and research presentations on cultural studies.

\section{References}

Abadiano, B. D. (2017). Sustaining Initiatives on Indigenous Peoples Education through Partnerships and Collaboration with Stakeholders. University of Southeastern Philippines.

Abayao, L. E. (2014). The Philippines Indigenous Peoples' Core Curriculum. UP Forum, UP.

Abejuela III, R. B. (n.d.). Indigenous Knowledge Systems and Higher Education in the Philippines.

Ancestry. (2008). What Is Material Culture? Antiques Roadshow. Retrieved from http://www.pbs.org/wgbh/roadshow/teachers_materialculture.html.

Babione, C. (2015). Practitioner Teacher Inquiry and Research: analysing, interpreting, $\quad$ and managing inquiry study. Jossey-Bass. San Francisco, CA. Pp. 139 - 166.

Bohensky, E. L. \& Maru, Y. (2011). Indigenous Knowledge, Science, and Resilience: What have we learned from a decade of international literature on "Integration". Ecology and Sciences, 6(4).

Brown, M. F. (2009). Who owns native culture? Harvard University Press.

Cajete, G. (1994). Look to the Mountain: An Ecology of Indigenous Education (1st Ed.). Retrieved from https://eric.ed.gov/?id=ED375993.

Calleja, N. (2011). DepEd approves plan for IP-sensitive educational system. Philippine Daily Inquirer. Retrieved from http://newsinfo.inquirer.net/38323/\%20deped-approves-plan-for-ip-sensitive-educational-system.

Champagne, D. (2009), Contemporary Education in State of the World's Indigenous Peoples, Ch. IV. UN Department of Economic and Social Affairs, ST/ESA/328.

Chermack, T. J. \& Kasshanna, B. K. (2007). The Use and Misuse of SWOT Analysis and Implications for HRD Professionals. Human Resource Development International, 10(4), 338-399.

Cleverism. (2016). 2017. How to Set Up a Center of Excellence. Retrieved from https://www.cleverism.com/howset-up-center-excellence/.

Cue, E. G. (2017). Cordilleras Cuisine in the HRMT Curriculum. Mountain Province State Polytechnic College, Bontoc, Mountain Province.

DepEd. (2016). DepEd launches first ever Basic Education Research Agenda. Retrieved from http://www.deped.gov.ph/press-releases/deped-launches-first-ever-basic-education-researchagenda.

DepEd. (2017). DepEd sustains support for culture-based education for IP learners. Retrieved from http://www.deped.gov.ph/press-releases/deped-sustains-support-culture-based-education-iplearners.

DepEd. (2011). Department Order 103 s. 2011. Creation of the Indigenous Peoples' Office (IPsEO). Retrieved from www.deped.gov.ph/sites/default/files/order/2011/DO_s2011_103.pdf.

DepEd CAR. (2015). CAR IPEd Curriculum Framework. Retrieved from http://www.depedcar.ph/Kto12-inCAR/car-iped-curiculumn-framework.

DepEd. (2016). DO 39, s. 2016. Adoption of the Basic Education Research Agenda. Retrieved from www.deped.gov.ph/orders/do-39-s-2016.

EMRIP. (2009). Study on lessons learned and challenges to achieve the implementation of the right of indigenous peoples to education: Report of the Expert Mechanism on the Rights of Indigenous Peoples. Human Rights Council,UNGA, A/HRC/EMRIP/2009/2. 
Empian, O. C. (2016). DepEd eyes Cordillera as model on IP Education in the country. News. Baguio Midland Courier. Retrieved from http://baguiomidlandcourier.com.ph/region.asp?mode $=\% 20$ archives $/ 2016 /$ october $/ 10-9-2016 /$ reg1.txt.

Ghazinoory, S., Abdi, M., \& Mehr, M. (2009). SWOT Methodology: A State- of-the-Art Review for the Past, A Framework for the Future. Journal of Business Economics and Management, 12(1), 24-48.

Haavisto, T. (2017). A Building is the Image of Its Function. Library Buildings Info. Retrieved from https://library buildings. info/articles/building-image-its-function.

Hoppers, C. (2002). Indigenous Knowledge and the Integration of Knowledge System: towards a philosophy of articulation. Retrieved from https://books.google.com. ph/books?hl=en\&lr=\&id.

Kader, T. (2000). Material Culture Studies and Art Education: Examining the Cultural Artifacts of the Bohra. Iowa Research Online. Retrieved from http://ir.uiowa.edu/cgi/viewcontent.cgi?article=1359\&context=mzwp.

Kasvio, M. (2008). Store and Share. Museums and Libraries in Finland Finnish Museum of Architecture. Finnish Museum of Architecture. Translation AAC NoodiOy. Retrieved from http://www.mfa.fi/publication?jid=11361822.

Kinomis, X. G. D. (2016). Indigenous Knowledge Systems and Practices (IKSPS) in the Teaching of Science.13th National Concention on Statistics, EDSA Shangri-La Hotel, Mandaluyong City. Pp. $1-8$.

Lavallee, L. F. (2009). Practical Application of an indigenous Research Methods: Sharing Circles and Anishnaalee Symbol- Based Reflection. International Journal of Qualitative Methods, 8(1), 21-40.

Mascio, A. D. (2012). Material Culture and Schooling: Possible New Explorations in the History of Canadian Education. Bishop's University. Retrieved from https://journals.lib.unb.ca/index.php/MCR/article/view/21411/24815.

Maguen, R. K. (2005). Integration of the Indigenous Knowledge and Practices in the Curricular Courses of Mountain Province State Polytechnic College. (Unpublished Dissertation on Doctor of Philosophy), Benguet State University. La Trinidad, Benguet.

Memebrere, E. (2016). Cordillera region eyed as IPED model. Sunstar Baguio (2018). Retrieved from http://www.sunstar. com.ph/baguio/local-news/2016/10/04/cordillera-region-eyed-iped-model501660 .

Michael, M. (1999). Where are Indigenous peoples and their knowledge in the reforming of learning, curriculum and pedagogy? UNESCO-ACEID International Conference. Bangkok, Thailand.

Micklay, A. K. (2017). Indigenizing the Curriculum. Herald Express, February Issue.

Mishra, P., \& Koehler, M. J. (2006). Technological pedagogical content knowledge: A framework for teacher knowledge. Teachers college record, 108(6), 1017.

Ngales, M. M. (n.d.). Institutionalizing Indigenous Education among the HEIs: Advancing the gains in inclusivity and equity in education. Lyceum of the Philippines University.

Pekas, G. A. (2016). Gadfly: Indigenousness. The Mountain Province Monitor. Official Publication of the Provincial Government. Mountain Province.

Peralta, L. S. (2014). Education of Indigenous Peoples in the Philippines vis-à-vis ASEAN Community. ASEAN Correspondent from the Philippines.

Rajasekaran, B. (1993). Retrospective Theses and Dissertations: A framework for incorporating indigenous knowledge systems into agricultural research and extension organizations for sustainable agricultural development in India. Iowa State University.

Reich, C. and Carrigan, T. (2017). Framework and Other Making Resources for Museums and Libraries. IMLS. Retrieved from https://www.imls.gov/blog/2017/06/framework-and-other-making-resourcesmuseums-and-libraries.

Ronen, B. \& Coman, A. (2009). Focused SWOT: diagnosing critical strengths and weaknesses. International Journal of Production Research, 47(20), 5677-5689.

Saley, J. B. (2012). Mt. Province holds 4th School of Living Tradition Convention. Ugnayan. PIA, Mtn. Province, Philippines.

Retrieved

from http://www.ugnayan.com/ph/MountainProvince/Sabangan/article/1AZ2.

Shinno, H., Yoshioka, H., Marpaung, S., \& Hachiga, S. (2007). Quantitative SWOT Analysis on global competitiveness of machine tool industry. Journal of Engineering Design, 17(3), 251-258.

Smith, L. T. (2005). Building a Research Agenda for Indigenous Epistemologies and Education. Anthro Source. American Anthropological Association, 26(1), 93-95.

Template Lab. (n.d). SWOT Analysis Template. Retrieved from http://templatelab.com/swot-analysistemplates/.

The Episcopal Commission on Indigenous Peoples. (n.d). Consolidate Report. Indigenous Peoples Education: "From Alienation to Rootedness". Indigenous Peoples Education, Philippines. Pp. 113-125.

The President and Fellows of Harvard College. (2017). Principles and Guidelines for the Establishment of Centers. Retrieved at https:// provost.harvard.edu/principles-and-guidelines-establishment-centers.

Thieman, G. Y. (2006). Using Technology as a Tool for Learning and Developing 21st Century Citizenship Skills: An Examination of the NETS and Technology Use by Preservice Teachers with Their K-12 Students University. Contemporary Issues In Technology And Teacher Education, 8(4).

United Nations. (2008). United Nations Declaration on the Rights of Indigenous Peoples (UNDRIP). Pp. 1-18. 
Universities Australia. (2011). Guiding Principles for the Development of Indigenous Cultural Competency in Australian Universities: Teaching and learning. Pp. 1-32. Retrieved from https://www.uow.edu.au/wic/index.html.

Vadil, C. F. (2008). Center for Nueva Viscaya Studies: Roles and Challenges. Paper Presented in the $2^{\text {nd }}$ National Convention on Indigenous People Higher Education in the Philippines at the University of Southeastern Philippines, Davao City.

Valencia, M. D. (n.d). Surfacing the Indigenous Knowledge Systems and Practices (IKSPs): Towards the Establishment of the SMYU School of Living Traditions. Saint Mary's University, Bayumbng, NuevaVizcaya, Philippines.

Valentin, E. K. (2015). SWOT Analysis from a Resource-Based View. Journal of Marketing Theory and Practice, 9(2), 54-69.

Victor, M. L. and Yano, B. (n.d.). Actualizing the Inclusion of Indigenous Peoples' Rights in Education: A Policy Initiatives in the Philippines. Retrieved from https://www.hurights.or.jp/archives/asiapacific/section $1 / 9 \% 20$ Indigenous $\% 20$ Peoples $\%$ E2\%80\%99\%20Rights $\% 20$ in $\% 20$ Education.pdf. 